\title{
СТРУКТУРА КОПІНГ-ПОВЕДІНКИ У ХВОРИХ ІЗ ПЕРВИННИМ ЕПІЗОДОМ БІПОЛЯРНОГО АФЕКТИВНОГО РОЗЛАДУ
}

\section{Тернопільський національний медичний університет імені І. Я. Горбачевського моз України}

РЕЗЮМЕ. Проблема біполярного афективного розладу (БАР) $є$ однією з найактуальніших у сучасній психіатрії.

Мета - дослідити особливості копінг-поведінки хворих із первинним епізодом біполярного афективного розладу з урахуванням гендерного фактора і клінічного варіанту дебюту БАР.

Матеріал і методи. Проаналізовано особливості копінг-поведінки у 153 хворих із первинним епізодом БАР 3 використанням опитувальника «Способи долаючої поведінки» S. Folkman i R. Lazarus в адаптації T. Л. Крюкової.

Результати. Встановлено, що при депресивному варіанті первинного епізоду переважають стратегії втечіуникнення - у 26,5 \% всіх хворих, у 25,2 \% чоловіків, у 27,3 \% жінок; прийняття відповідальності - 17,5 \%, 15,2 \%, 18,9 \%; пошуку соціальної підтримки - 17,5 \%, 16,3 \%, 18,3 \%; менше значення мають самоконтроль - 13,0 \%, 14,4 \%, $12,1 \%$; дистанціювання - 8,3 \%, 8,0 \%, 8,5 \%; планування вирішення проблеми - 7,7 \%, 9,1 \%, 6,9\%; конфронтаційний копінг - 6,5 \%, 8,5 \%, 5,3 \% і позитивна переоцінка - 2,9 \%, 3,3 \%, 2,7 \%. При маніакальному варіанті домінують конфронтаційний копінг - 26,6 \%, 28,4 \%, 23,1 \%; рідше дистанціювання - 17,8 \%, 21,0 \%, 11,9 \%; втеча-уникнення $15,6 \%, 13,8 \%, 19,0 \%$; позитивна переоцінка - 15,3\%, 15,7 \%, 14,5 \%; планування вирішення проблеми - 9,1 \%, 9,0 \%, 9,2\%; самоконтролю-7,3\%, 6,0\%, 9,8\%; пошуку соціальноїпідтримки-6,6\%, 4,9\%, 9,9\% іприйняття відповідальності1,7 \%, 1,2 \%, 2,6 \%. При змішаному варіанті переважають дистанціювання - 20,9 \%, 19,2 \%, 22,9 \%; втеча-уникнення $18,8 \%, 17,2 \%, 20,7 \%$; конфронтаційний копінг - 18,1\%, 24,4 \%, 11,0\%; менше значення мають пошук соціальної підтримки - 14,8 \%, 10,1 \%, 20,0 \%; самоконтроль - 9,4 \%, 8,1 \%, 10,9 \%; прийняття відповідальності - 6,0 \%, 6,8 \%, 5,1 \%; позитивна переоцінка - 6,2 \%, 7,1%, 5,1 \% і планування вирішення проблеми - 5,8 \%, 7,1%, 4,3 \%.

Висновки. Хворим із первинним епізодом БАР притаманні гендерні особливості копінг-поведінки, що полягають у переважанні в чоловіків конфронтаційного копінгу, самоконтролю, планування вирішення проблеми і позитивної переоцінки, а у жінок - дистанціювання, пошуку соціальної підтримки, прийняття відповідальності і втечі-уникнення. Вирішальне значення для копінг-поведінки має клінічний варіант первинного епізоду, при цьому депресивний варіант асоційований зі стратегіями втечі-уникнення, прийняття відповідальності і пошуку соціальної підтримки; маніакальний - зі стратегіями конфронтаційного копінгу, дистанціювання та втечі-уникнення, а при змішаному варіанті вибір копінг-стратегії визначається актуальним психічним станом.

КЛючОВІ СлОВА: біполярний афективний розлад; первинний епізод; копінг-поведінка.

Вступ. Проблема біполярного афективного розладу (БАР) $є$ однією з найактуальніших медичних та соціальних проблем [1-3]. Дослідження первинного епізоду (ПЕ) БАР має важливе значення для подальших лікувально-реабілітаційних заходів, при цьому ініціальні характеристики захворювання залишаються недослідженими, а низька прогностична цінність існуючих предикторів вимагає удосконалення інструментів продромальної ідентифікації [4]. Характер майбутнього біполярного розладу зумовлений характером початкових чи ранніх епізодів захворювання; при цьому особливості ПЕ $\epsilon$ важливим чинником прогнозування тяжкості захворювання, функціональних наслідків та відповіді на лікування; при цьому у значній частині випадків від первинних проявів до встановлення діагнозу БАР може проходити від 3 до 11 років [5]. Первинні прояви БАР виявляються за кілька років до синдромально оформленого розладу, а система первинної оцінки та прогнозування БАР на ранніх етапах потребує удосконалення [6]; також слід приділяти більшу увагу аналізу перших проявів БАР, що можуть бути використані в якості актуальних антецедентів захво- рювання [7]. Дослідження особливостей копінгповедінки має важливе значення для комплексної оцінки патоперсонологічних особливостей хворих із БАР [8]. Психологічні механізми подолання проблем у різних сферах психічної діяльності $є$ одним з ключових компонентів психосоціального функціонування особистості, і їх аналіз дає можливість адекватної оцінки когнітивних i поведінкових реакцій індивіда, спрямованих на адаптацію до мінливих умов зовнішнього середовища і усунення або зменшення впливу негативних життєвих обставин. Останніми роками були одержані дані щодо зв'язку між афективними станами при БАР та поведінкою, спрямованою на подолання стресу [9], встановлено потенційний ризик прогресування БАР при неефективних копінгстратегіях [10], однак дослідження копінг-поведінки при ПЕ БАР на сьогодні відсутні. Це утруднює розробку ефективних лікувально-реабілітаційних та профілактичних заходів при БАР.

Мета-дослідити особливості копінг-поведінки хворих із первинним епізодом біполярного афективного розладу з урахуванням гендерного фактора і клінічного варіанту дебюту БАР. 
Огляди літератури, оригінальні дослідження, погляд на проблему, випадок з практики, короткі повідомлення

Матеріал і методи дослідження. 3 дотриманням принципів біомедичної етики на підставі інформованої згоди нами було обстежено 153 хворих (65 чоловіків та 88 жінок) з первинним епізодом (ПЕ) біполярного афективного розладу, які перебували на лікуванні у Тернопільській обласній психоневрологічній лікарні у 2011-2016 роках. Середній вік обстежених пацієнтів на момент виникнення симптоматики склав $(21,3 \pm 6,5)$ років (медіана 19,0 років, інтерквартильний діапазон 17,022,0 років), чоловіків - $(20,5 \pm 5,8)$ років $(18,0$ років, $17,0-21,0$ років), жінок - $(21,9 \pm 6,9)$ років $(18,5$ років, 18,5-22,5 років), вік на момент звернення за медичною допомогою і обстеження - відповідно $(21,4 \pm 6,4)$ років $(19,0$ років, $18,0-22,0$ років), $(20,7 \pm$ $5,7)$ років $(18,0$ років, $17,0-21,0$ років) та $(22,0 \pm 6,9)$ років (19,0 років, 18,5-22,5 років).

Серед обстежених чоловіків і жінок нами було виділено по три групи в залежності від клінічного варіанту перебігу ПЕ БАР: з переважанням депресивної симптоматики (депресивний варіант), чисельністю 119 осіб (44 чоловіки і 75 жінок); з переважанням маніакальної або гіпоманіакальної симптоматики (маніакальний варіант), чисельністю 23 особи (15 чоловіків і 8 жінок), та з одночасною наявністю депресивної та маніакальної симптоматики або зі швидкою зміною фаз (змішаний варіант), чисельністю 11 осіб (6 чоловіків і 5 жінок).

Обстеження проведено з використанням опитувальника «Способи долаючої поведінки» S. Folkman i R. Lazarus в адаптації Т. Л. Крюкової [11].
Статистичну обробку отриманих даних проводили з використанням непараметричного тесту Манна-Уїтні і точного критерію Фішера.

Результати й обговорення. При дослідженні особливостей копінг-поведінки було виявлено наявність у хворих специфічних копінг-моделей, при цьому в хворих із різними варіантами ПЕ БАР були виявлені значущі відмінності, а також відмінності, пов'язані з впливом гендерного фактора.

При депресивному варіанті ПЕ БАР середні значення показників за окремими видами копінгу склали: конфронтаційний копінг - у всіх хворих $(17,47 \pm 14,28)$ балів, у чоловіків $(23,11 \pm 19,27)$ балів і у жінок $(14,16 \pm 8,91)$ балів (розбіжності між чоловіками і жінками статистично значущі, $\mathrm{p<0,05);} \mathrm{дистанцію-}$ вання -відповідно $(22,41 \pm 13,90)$ балів, $(21,72 \pm 10,29)$ балів і $(22,81 \pm 15,69)$ балів $(p>0,05)$; самоконтроль $(34,89 \pm 13,36)$ балів, $(38,85 \pm 14,30)$ балів і $(32,57 \pm$ $12,28)$ балів ( $<0,05)$; пошук соціальної підтримки $(47,23 \pm 18,11)$ балів, $(44,05 \pm 18,38)$ балів і $(49,09 \pm$ $17,81)$ балів ( $<<0,05)$; прийняття відповідальності $(47,20 \pm 22,46)$ балів, $(41,10 \pm 24,93)$ балів і $(50,77 \pm$ $20,19)$ балів $(p<0,05)$; втеча-уникнення - $(71,50 \pm$ $11,62)$ балів, $(68,10 \pm 9,37)$ балів і $(73,50 \pm 12,38)$ балів ( $p<0,05)$; планування вирішення проблеми - $(20,83 \pm$ $12,49)$ балів, $(24,62 \pm 12,01)$ балів і $(18,60 \pm 12,30)$ балів $(p<0,05)$; позитивна переоцінка - $(7,88 \pm 8,27)$ балів, $(8,98 \pm 6,50)$ балів і $(7,24 \pm 9,13)$ балів $(p<0,05)$.

У хворих з депресивним варіантом ПЕ БАР домінуючою копінг-стратегією $є$ втеча-уникнення (рис. 1).

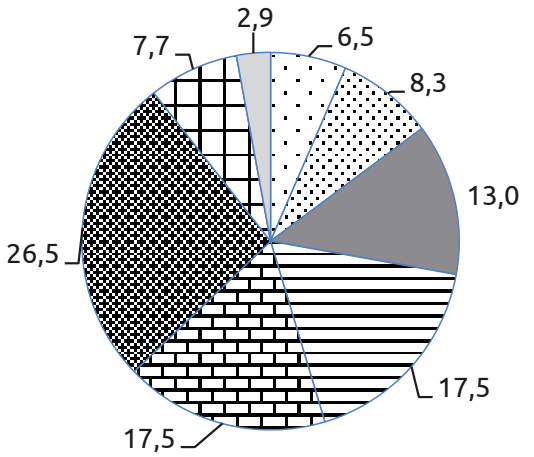

๑ Конфронтаційний копінг

曰Пошук соціальної підтримки

口Планування вирішення проблеми

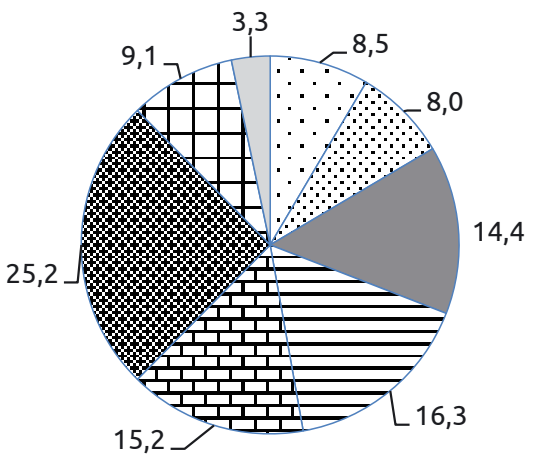

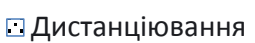

ВПрийняття відповідальності

$\square$ Позитивна переоцінка

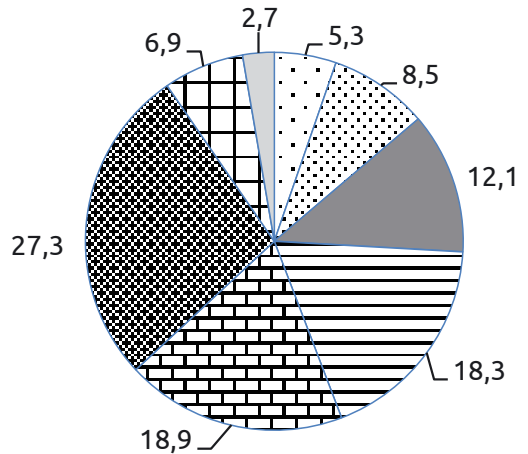

- Самоконтроль

Втеча-уникнення

Рис. 1. Структура варіантів копінг-поведінки у хворих з депресивним варіантом ПЕ БАР (співвідношення варіантів копінгу за їх кількісними значеннями, \%).

У хворих з депресивним варіантом ПЕ БАР реакція втечі-уникнення реалізується переважно у вигляді відсторонення від будь-якої діяльності внаслідок притаманної депресивному стану гіпо- тимії, брадипсихізму і загальмованості, а не лише по відношенню до фруструючого агента. Важливо, що депресивний стан сам по собі $\epsilon$ потужним психоемоційним стресом, здатним спричинити 
Огляди літератури, оригінальні дослідження, погляд на проблему, випадок з практики, короткі повідомлення радикальну зміну психічного гомеостазу. Усе це зумовлює специфічний копінг-патерн, який при депресивному варіанті ПЕ БАР ґрунтується на універсальній реакції зменшення інтенсивності психічних реакцій у відповідь на розвиток депресивної симптоматики і пов'язаним з цим прагненням уникати будь-якої активності, включаючи активність, спрямовану на подолання проблеми. При депресивному варіанті ПЕ БАР реакції втечі-уникнення поєднуються з реакціями прийняття відповідальності і пошуку соціальної підтримки. Копінгстратегія прийняття відповідальності у хворих 3 депресивним варіантом ПЕ БАР набуває характеру хворобливої самокритики і самозвинувачення, аж до формування клінічно оформлених ідей самоприниження і самозвинувачення. Копінг-стратегія пошуку соціальної підтримки у хворих з депресивним варіантом ПЕ БАР реалізується переважно в пошуку співчуття, емпатії, емоційної підтримки і допомоги в полегшенні тяжких афективних переживань, пов'язаних з депресією. Суттєво менше серед хворих з депресивним варіантом ПЕ БАР поширена копінг-стратегія самокон-

тролю, що полягає у намаганні стримувати i пригнічувати негативні емоції, мінімізувати їх неприємний вплив, контролювати власну поведінку; у дослідженого контингенту ця копінг-стратегія проявляється намаганням насамперед взяти під контроль депресивні переживання. 3 копінгстратегією самоконтролю у хворих із депресивним варіантом ПЕ БАР часто була пов'язана стратегія дистанціювання, що полягає у намаганні зменшити суб'єктивне значення проблеми і емоційне залучення до неї за рахунок використання інтелектуальних прийомів раціоналізації, переключення уваги, відсторонення, гумору, знецінення тощо. Ця стратегія також використовувалася насамперед з метою послаблення депресивних переживань і асоційованої з ними соматовегетативної симптоматики. Найменш типовими для хворих з депресивним варіантом ПЕ БАР виявилися копінгстратегії планування вирішення проблеми, конфронтаційного копінгу та позитивної переоцінки.

У хворих з маніакальним варіантом ПЕ БАР структура копінг-стратегії суттєво відрізняється (рис. 2).

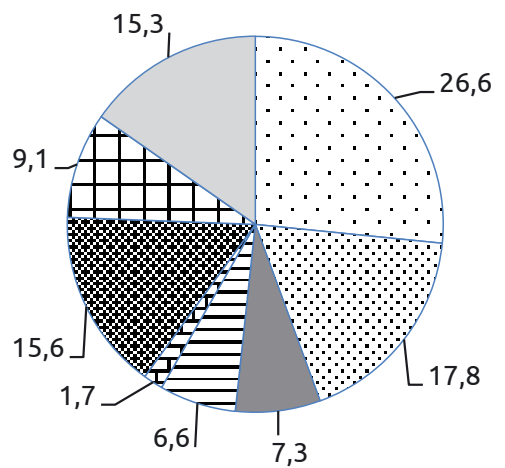

$\square$ Конфронтаційний копінг

च Пошук соціальної підтримки

п Планування вирішення проблеми

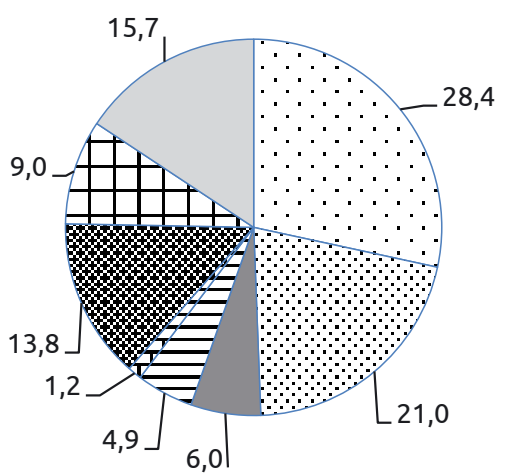

๑ Дистанціювання

пПрийняття відповідальності

пПозитивна переоцінка

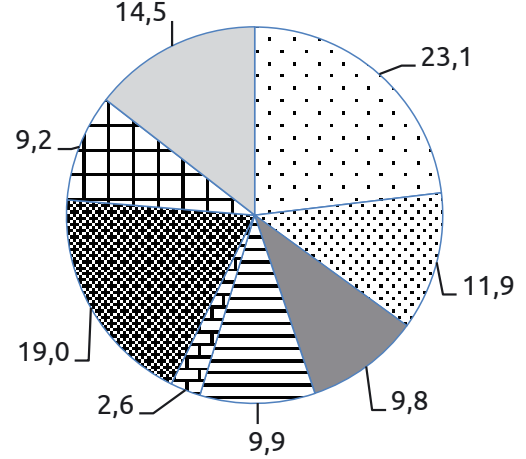

Самоконтроль

В Втеча-уникнення

Рис. 2. Структура варіантів копінг-поведінки у хворих із маніакальним варіантом ПЕ БАР (співвідношення варіантів копінгу за їх кількісними значеннями, \%).

Середні значення за окремими копінг-стратегіями при маніакальному варіанті ПЕ БАР склали: конфронтаційний копінг- $(84,53 \pm 16,07)$ балів, $(90,74 \pm$ $3,41)$ балів і $(72,90 \pm 23,48)$ балів $(p<0,05)$; дистанціювання - $(56,77 \pm 28,92)$ балів, $(67,05 \pm 21,57)$ балів i $(37,50 \pm 32,36)$ балів $(p<0,05)$; самоконтроль - $(23,19 \pm$ $20,31)$ балів, $(19,06 \pm 20,11)$ балів і $(30,94 \pm 19,55)$ балів ( $<<0,05)$; пошук соціальної підтримки - $(21,01 \pm$ $15,87)$ балів, $(15,56 \pm 17,33)$ балів і $(31,24 \pm 2,85)$ балів ( $<<0,05)$; прийняття відповідальності- $(5,43 \pm 8,18)$ балів, $(3,89 \pm 9,37)$ балів і $(8,31 \pm 4,46)$ балів $(p<0,05)$; втеча-уникнення-(49,65 $\pm 19,75) 6 а л і в,(44,18 \pm 20,83) 6 а-$ лів і $(59,90 \pm 13,18)$ балів $(p<0,05)$; планування вирішення проблеми - $(28,97 \pm 13,81)$ балів, $(28,87 \pm$ $16,43)$ балів і $(29,15 \pm 7,70)$ балів $(p>0,05)$; позитивна переоцінка - $(48,65 \pm 22,88)$ балів, $(50,15 \pm 20,66)$ балів і $(45,83 \pm 27,88)$ балів ( $>>0,05)$. Найпоширенішою копінг-стратегією у цих хворих виявився конфронтаційний копінг, який у дослідженого контингенту проявляється у надмірній, переважно хаотичній активності, зумовленій наявністю маніакального і гіпоманіакального стану, активному спротиві спро- 
Огляди літератури, оригінальні дослідження, погляд на проблему, випадок з практики, короткі повідомлення бам оточуючих обмежити цю патологічну активність, спалахах роздратування та агресії у відповідь на стримувальні заходи і неможливість задовольнити поточні бажання, що при маніакальному стані $є$ спонтанними і швидкоплинними. Меншою $\epsilon$ виразність дистанціювання, що у хворих з маніакальним варіантом ПЕ БАР набувало переважно характеру відволікання уваги, знецінення і відсторонення від проблем при практично незадіяному механізмі раціоналізації; втечі-уникнення, яке реалізувалося насамперед за механізмом заперечення проблеми; та позитивної переоцінки, що при маніакальному варіанті ПЕ БАР було представлено не стільки переосмисленням проблеми як ресурсу для особистісного росту, скільки зумовленою маніакальним станом схильністю розглядати усі події життя як позитивні. Нетиповими для хворих з маніакальним варіантом ПЕ БАР виявилися стратегії планування вирішення проблеми, самоконтролю і пошуку соціальної підтримки, а найменш вираженою - копінг-стратегія прийняття відповідальності.

Найбільш складні закономірності копінг-стратегій були виявлені у хворих зі змішаним варіантом ПЕ БАР (рис. 3). Вони поєднували характеристики, виявлені у хворих з депресивним варіантом ПЕ БАР з деякими особливостями, притаманними хворим з маніакальним варіантом. Середні значення показників за окремими копінг-стратегіями склали: конфронтаційний копінг - $(45,95 \pm 23,97)$ балів, $(60,18 \pm 21,19)$ балів і $(28,88 \pm 14,38)$ балів $(p<0,05)$; дистанціювання - $(53,05 \pm 17,64)$ балів, $(47,23 \pm 21,02)$ балів і $(60,02 \pm 10,69)$ балів ( $>0,05)$; самоконтроль $(23,80 \pm 27,51)$ балів, $(19,83 \pm 38,13)$ балів і $(28,56 \pm$ $4,75)$ балів ( $>0,05) ;$ пошук соціальної підтримки $(37,37 \pm 20,95)$ балів, $(25,00 \pm 15,99)$ балів і $(52,22 \pm$ $16,51)$ балів ( $<0,05)$; прийняття відповідальності $(15,15 \pm 9,74)$ балів, $(16,68 \pm 9,13)$ балів і $(13,32 \pm 11,19)$ балів ( $>0,05)$; втеча-уникнення - $(47,74 \pm 9,57)$ балів, $(42,37 \pm 8,07)$ балів і $(54,18 \pm 7,23)$ балів $(p<0,05)$; планування вирішення проблеми - $(14,65 \pm 13,21)$ балів, $(17,60 \pm 16,26)$ балів і $(11,12 \pm 8,78)$ балів $(p>0,05)$; позитивна переоцінка - $(15,58 \pm 13,97)$ балів, $(17,45 \pm$ $16,67)$ балів і $(13,34 \pm 11,37)$ балів $(p>0,05)$.
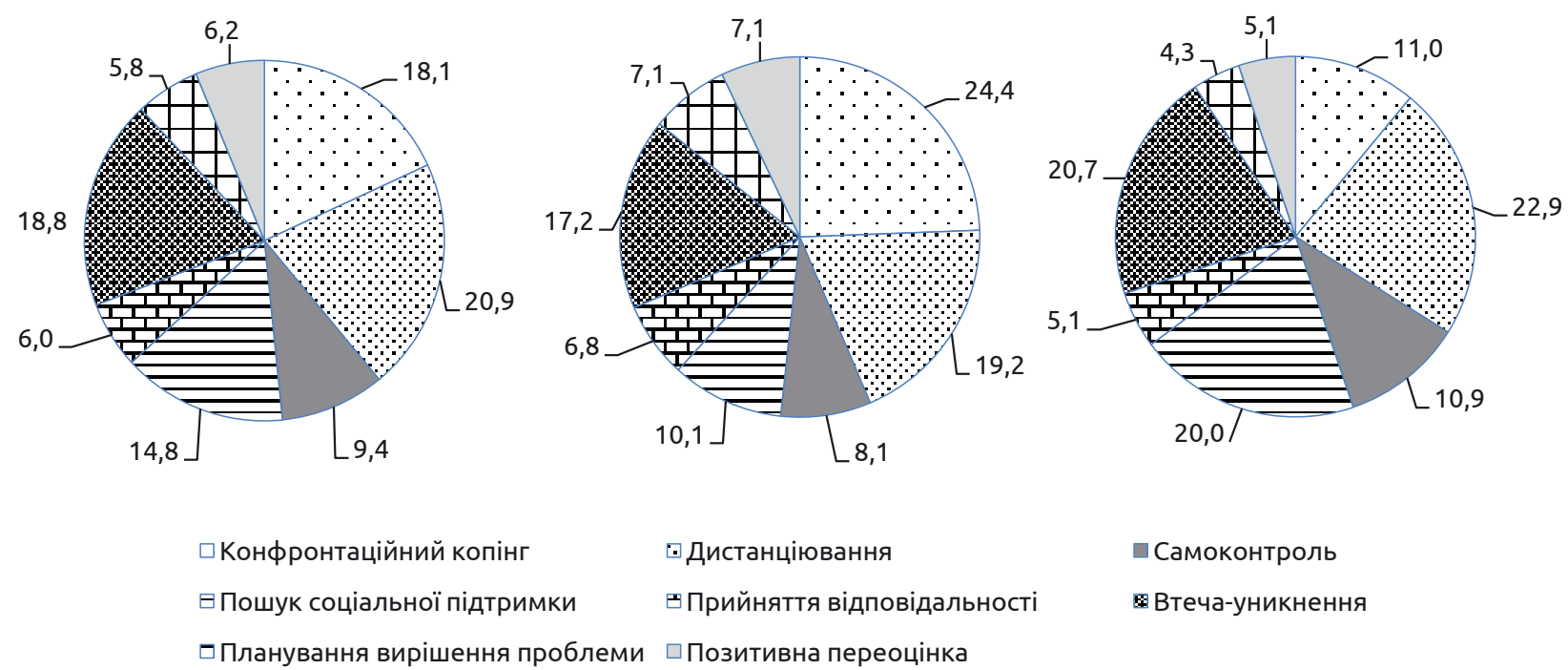

- Самоконтроль

圈 Втеча-уникнення

Рис. 3. Структура варіантів копінг-поведінки у хворих зі змішаним варіантом ПЕ БАР (співвідношення варіантів копінгу за їх кількісними значеннями, \%).

Найбільш вираженими у цих хворих були копінг-стратегії дистанціювання, втечі-уникнення i конфронтаційного копінгу, менш вираженими пошук соціальної підтримки і самоконтроль, і найменшими - позитивна переоцінка, прийняття відповідальності і планування вирішення проблеми. Слід зауважити, що при змішаному варіанті результати тесту значною мірою визначалися особливостями актуального психоемоційного стану хворого: при переважанні в клінічній картині депресивних і субдепресивних проявів особливості копінг-поведінки були близькими до притаманних хворим з депресивним варіантом дебюту, а при переважанні маніакальних і гіпоманіакальних проявів - до хворих з маніакальним варіантом ПЕ БАР.

Висновки. 1. Хворим з ПЕ БАР притаманні певні особливості копінг-поведінки, асоційовані 3 клінічними особливостями захворювання.

2. При депресивному варіанті ПЕ БАР переважають копінг-стратегії втечі-уникнення, прийняття відповідальності і пошуку соціальної підтримки, що пов'язані з притаманними депресивному стану гіпотимією, брадипсихізмом і загальмованістю. 
Огляди літератури, оригінальні дослідження, погляд на проблему, випадок з практики, короткі повідомлення

3. При маніакальному варіанті ПЕ БАР переважають копінг-стратегії конфронтаційного копінгу, дистанціювання та втечі-уникнення, що мають певні відмінності, зумовлені гіперактивністю і поведінковою розгальмованістю, притаманною маніакальному стану.

4. При змішаному варіанті ПЕ БАР вибір копінгстратегії визначається актуальним психічним станом і при переважанні депресивних і субдепресивних проявів відповідає характерному для хворих 3 депресивним варіантом ПЕ БАР, а при переважанні маніакальних і гіпоманіакальних проявів - маніакальному.

\section{ЛІТЕРАТУРА}

1. Mental health: strengthening our response / Information Bulletin of World Health Organisation. - Geneva, WHO, 2018. - P. 1-28.

2. Delays before diagnosis and initiation of treatment in patients presenting to mental health services with bipolar disorder / R. Patel, H. Shetty, R. Jackson [et al.] // PLoS One. - 2015. - Vol. 10. - P. 126-129.

3. Cognitive functioning in first episode bipolar I disorder patients with and without history of psychosis / T. Chakrabarty, G. Alamian, J. M. Kozicky [et al.] // Journal of Affective Disorders. - 2018. - Vol. 227. - P. 109-116.

4. Rowland T. A. Epidemiology and risk factors for bipolar disorder / T. A. Rowland, S. Marwaha // Therapeutic Advances in Psychopharmacology. - 2018. - Vol. 8 (9). P. 251-269.

5. Baldessarini R. J. First-episode types in bipolar disorder: predictive associations with later illness / R. J. Baldessarini, L. Tondo, C. Visioli // Acta Psychiatrica Scandinavica. - 2014. - Vol. 129. - P. 383-392.

6. Clinical risk factors for bipolar disorders: a systematic review of prospective studies / G. L. Faedda, G. Serra, C. Marangoni [et al.] // Journal of Affective Disorders. 2014. - Vol. 168. - P. 314-321.

\section{REFERENCES}

1. Mental health: strengthening our response (2018). Information Bulletin of World Health Organisation. Geneva, WHO, 1-28.

2. Patel, R., Shetty, H., Jackson, R., Broadbent, M., Stewart, R., \& Boydell, J. (2015). Delays before diagnosis and initiation of treatment in patients presenting to mental health services with bipolar disorder. PLoS One, 10, 126-129.

3. Chakrabarty, T., Alamian, G., Kozicky, J.M., Ivan, J.T., \& Lakshmi, N.Y. (2018). Cognitive functioning in first episode bipolar I disorder patients with and without history of psychosis. Journal of Affective Disorders, 227, 109-116.

4. Rowland, T.A., \& Marwaha, S. (2018). Epidemiology and risk factors for bipolar disorder. Therapeutic Advances in Psychopharmacology, 8 (9), 251-269.

5. Baldessarini, R.J., Tondo, L., \& Visioli, C. (2014). First-episode types in bipolar disorder: predictive associations with later illness. Acta Psychiatrica Scandinavica, 129,
5. Гендерні відмінності копінг-поведінки полягають у переважанні у чоловіків конфронтаційного копінгу, самоконтролю, планування вирішення проблеми і позитивної переоцінки, а у жінок - дистанціювання, пошуку соціальної підтримки, прийняття відповідальності і втечі-уникнення.

Перспективи подальших наукових досліджень пов'язані з розробкою на підставі даних дослідження комплексних програм лікування та реабілітації хворих з ПЕ БАР.

7. Antecedents of manic versus other first psychotic episodes in 263 bipolar I disorder patients / P. Salvatore, R. J. Baldessarini, H. M. Khalsa [et al.] // Acta. Psychiatrica Scandinavica. - 2014. - Vol. 129. - P. 275-285.

8. Moment-to-moment interaction between affectivity and coping behaviours in bipolar disorder and the role of cognitive appraisals / M. H. Leung, S. H. So, N. T. Kwok [et al.] // BJPsych. Open. - 2019. - Vol. (3). - P. 44-48.

9. Associations among depressive symptoms, childhood abuse, neuroticism, social support, and coping style in the population covering general adults, depressed patients, bipolar disorder patients, and high risk population for depression / J. Zhou, L. Feng, C. Hu [et al.] // Front. Psychol. - 2019. - Vol. 10. - P. 1321-1323.

10. Nijjar R. Personality, coping, risky behavior, and mental disorders in the offspring of parents with bipolar disorder: a comprehensive psychosocial assessment / R. Nijjar, M. A. Ellenbogen, S. Hodgins // Journal of Affective Disorders. - 2014. - Vol. 166. - P. 315-323.

11. Крюкова Т. Л. Опросник способов совладания (адаптация методики WCQ) / Т. Л. Крюкова, Е. В. Куфтяк // Журнал практического психолога. - 2007. - № 3. С. 93-112.

383-392.

6. Faedda, G.L., Serra, G., Marangoni, C., Salvatore, P., Sani, G., Vázquez, G.H., ..., \& Koukopoulos, A. (2014). Clinical risk factors for bipolar disorders: a systematic review of prospective studies. Journal of Affective Disorders, $168,314-321$.

7. Salvatore, P., Baldessarini, R.J., \& Khalsa, H.M. (2014). Antecedents of manic versus other first psychotic episodes in 263 bipolar I disorder patients. Acta Psychiatrica Scandinavica, 129, 275-285.

8. Leung, M.H., So, S.H., Kwok, N.T., Ng, I.H., Chan, P.S., Lo, C.C., ..., \& Lee, S. (2019). Moment-to-moment interaction between affectivity and coping behaviours in bipolar disorder and the role of cognitive appraisals. BJPsych. Open, 3, 44-48.

9. Zhou, J., Feng, L., Hu, C., Pao, C., Xiao, L., \& Wang, G. (2019). Associations among depressive symptoms, child- 
Огляди літератури, оригінальні дослідження, погляд на проблему, випадок з практики, короткі повідомлення hood abuse, neuroticism, social support, and coping style in the population covering general adults, depressed patients, bipolar disorder patients, and high risk population for depression. Front. Psychol., 10, 1321-1323.

10. Nijjar, R., Ellenbogen, M.A., \& Hodgins, S. (2014). Personality, coping, risky behavior, and mental disorders in the offspring of parents with bipolar disorder: a comprehensive psychosocial assessment. Journal of Affective Disorders, 166, 315-323.

11. Kryukova, T.L., \& Kuftyak, E.V. (2007). Oprosnik sposobov sovladaniya (adaptaciya metodiki WCQ) [Coping methods questionnaire]. Zhurnal prakticheskogo psikhologa - Journal of Practical Psychologist, 3, 93-112 [in Russian].

\title{
СТРУКТУРА КОПИНГ-ПОВЕДЕНИЯ У БОЛЬНЫХ С ПЕРВИЧНЫМ ЭПИЗОДОМ БИПОЛЯРНОГО АФФЕКТИВНОГО РАССТРОЙСТВА
}

\author{
Тернопольский национальный медицинский университет имени И. Я. Горбачевского МОЗ Украины
}

РЕЗЮМЕ. Проблема биполярного аффективного расстройства является одной из наиболее актуальных проблем современной психиатрии.

Цель - изучить особенности копинг-поведения больных с первичным эпизодом биполярного аффективного расстройства с учетом гендерного фактора и клинического варианта дебюта БАР.

Материал и методы. Проанализированы особенности копинг-поведения 153 больных с первичным эпизодом БАР с использованием опросника «Способы преодолевающего поведения» S. Folkman и R. Lazarus в адаптации Т. Л. Крюковой.

Результаты. Установлено, что при депрессивном варианте первичного эпизода преобладают стратегии бегства-избегания - у 26,5 \% всех больных, у 25,2 \% мужчин, у 27,3 \% женщин; принятия ответственности - 17,5 \%, $15,2 \%, 18,9 \%$; поиска социальной поддержки - 17,5 \%, 16,3 \%, 18,3 \%; меньшее значение имеют самоконтроль $13,0 \%, 14,4 \%, 12,1 \%$; дистанцирование - 8,3 \%, 8,0 \%, 8,5 \%; планирование решения проблемы - 7,7 \%, 9,1\%, 6,9\%; конфронтационный копинг - 6,5 \%, 8,5 \%, 5,3 \% и позитивная переоценка - 2,9 \%, 3,3%, 2,7 \%. При маниакальном варианте доминируют конфронтационный копинг - 26,6 \%, 28,4 \%, 23,1 \%; реже дистанцирование - 17,8 \%, 21,0 \%, 11,9 \%; бегство-избегание - 15,6 \%, 13,8 \%, 19,0 \%; позитивная переоценка - 15,3 \%, 15,7 \%, 14,5 \%; планирование решения проблемы - 9,1 \%, 9,0 \%, 9,2 \%; самоконтроля - 7,3 \%, 6,0 \%, 9,8 \%; поиска социальной поддержки - 6,6 \%, 4,9 \%, 9,9 \% и принятия ответственности - 1,7 \%, 1,2 \%, 2,6 \%. При смешанном варианте преобладают дистанцирование - 20,9 \%, 19,2 \%, 22,9 \%; бегство-избегание - 18,8 \%, 17,2 \%, 20,7 \%; конфронтационный копинг - 18,1 \%, 24,4 \%, 11,0 \%; меньшее значение имеют поиск социальной поддержки - 14,8 \%, 10,1 \%, 20,0 \%; самоконтроль $9,4 \%, 8,1 \%, 10,9 \%$; принятие ответственности - 6,0 \%, 6,8 \%, 5,1\%; положительная переоценка - 6,2 \%, 7,1 \%, 5,1 \% и планирование решения проблемы - 5,8\%, 7,1\%, 4,3\%.

Выводы. Больным с первичным эпизодом БАР присущи гендерные особенности копинг-поведения, заключающиеся в преобладании у мужчин конфронтационного копинга, самоконтроля, планирования решения проблемы и положительной переоценки, а у женщин - дистанцирования, поиска социальной поддержки, принятия ответственности и бегства-избегания. Решающее значение для копинг-поведения имеет клинический вариант первичного эпизода, при этом депрессивный вариант ассоциирован со стратегиями бегства-избегания, принятия ответственности и поиска социальной поддержки; маниакальный - со стратегиями конфронтационного копинга, дистанцирования и бегства-избегания, а при смешанном варианте выбор копинг-стратегии определяется актуальным психическим состоянием.

КЛЮЧЕВЫЕ СЛОВА: биполярное аффективное расстройство; первичный эпизод; копинг-поведение.

\section{STRUCTURE OF COPING-BEHAVIOR IN PATIENTS WITH PRIMARY EPISODE OF BIPOLAR AFFECTIVE DISORDER}

\section{Horbachevsky Ternopil National Medical University}

@Yu. I. Mysula

SUMMARY. Problem of bipolar affective disorder (BAD) is one of the actual problems in modern psychiatry.

The aim of the study is to investigate the coping behavior of patients with a primary episode of bipolar affective disorder, taking into account the gender factor and clinical variant of the BAD debut.

Material and Methods. The features of coping behavior in 153 patients with primary episode of BAD were analyzed using the Surveillance Behavior Questionnaire S. Folkman and R. Lazarus.

Results and Discussion. It was found that in the depressive variant of the primary episode, escape-avoidance strategies prevail $-26.5 \%$ of all patients, $25.2 \%$ of men, $27.3 \%$ of women; accepting responsibility - $17.5 \%, 15.2 \%$, 
Огляди літератури, оригінальні дослідження, погляд на проблему, випадок з практики, короткі повідомлення $18.9 \%$; seeking social support - $17.5 \%, 16.3 \%, 18.3 \%$; less important are self-control - $13.0 \%, 14.4 \%, 12.1 \%$; distance $8.3 \%, 8.0 \%$, $8.5 \%$; planning of problem solving - 7.7 \%, 9.1\%, 6.9 \%; confrontational coping - 6.5 \%, $8.5 \%$, $5.3 \%$ and positive revaluation $-2.9 \%, 3.3 \%, 2.7 \%$. In the maniacal version, confrontational coping is dominant - 26.6 \%, $28.4 \%$, $23.1 \%$; at least distance $-17.8 \%, 21.0 \%, 11.9 \%$; escape-avoidance - 15.6\%, $13.8 \%, 19.0 \%$; positive revaluation - $15.3 \%$, $15.7 \%, 14.5 \%$; planning of problem solving - 9.1\%, $9.0 \%$, $9.2 \%$; self-control - 7.3\%, $6.0 \%$, $9.8 \%$; seeking social support $6.6 \%, 4.9 \%, 9.9 \%$ and accepting responsibility $-1.7 \%, 1.2 \%, 2.6 \%$. In the mixed version, distance prevails - $20.9 \%$, $19.2 \%, 22.9 \%$; escape-avoidance - $18.8 \%, 17.2 \%, 20.7 \%$; confrontational coping - $18.1 \%, 24.4 \%, 11.0 \%$; less important are the search for social support - $14.8 \%, 10.1 \%, 20.0 \%$; self-control - 9.4 \%, $8.1 \%, 10.9 \%$; accepting responsibility $6.0 \%, 6.8 \%, 5.1 \%$; positive revaluation $-6.2 \%, 7.1 \%, 5.1 \%$ and problem solving planning $-5.8 \%, 7.1 \%, 4.3 \%$.

Conclusions. Patients with a primary episode of BAD have gender-specific coping behaviors that are predominant in men's confrontational coping, self-control, problem-solving planning and positive reassessment, and women have distancing, seeking social support, accepting responsibility, and escape-avoidance. The clinical version of the primary episode is crucial to coping behavior, with the depressive variant associated with escape, avoidance, responsibility, and social support strategies; maniacal - with strategies of confrontational coping, distance and escape-avoidance, and in the mixed version, the choice of coping strategy is determined by the actual mental state.

KEY WORDS: bipolar affective disorder; primary episode; coping behavior. 